\title{
Herpetofauna community structure and distribution of Watu Joglo cave area, Gunung Kidul, Special Region of Yogyakarta
}

\author{
Khadija Lung Ayu ${ }^{1,}{ }^{*}$, Nishfi Laila Maghfiroh ${ }^{1}$, Afghan Azka Falah $^{1}$, Muhammad Haekal ${ }^{1}$, Alfonsus Toribio Eko Saputro ${ }^{1}$, \\ Donan Satria Yudha ${ }^{2}$ \\ ${ }^{1}$ Herpetology Study Club, Universitas Gadjah Mada, Faculty of Biology, Tropical Biology Departement, 55281 Teknika Selatan Street, \\ Sleman, Indonesia \\ ${ }^{2}$ Animal Systematic Laboratory, Universitas Gadjah Mada, Faculty of Biology, Tropical Biology Departement, 55281 Teknika Selatan \\ Street, Sleman, Indonesia
}

\begin{abstract}
Watu Joglo is one of the caves located in the row of the Sewu mountains, Gunung Kidul, Special Regency of Yogyakarta. Watu Joglo has various suitable microhabitats for herpetofauna. So far, the study about herpetofauna's community structure and distribution has not been carried out in Watu Joglo. This study aimed to study and map the diversity, richness, evenness, and distribution of herpetofauna in Watu Joglo. Herpetofauna's data sampling was carried out for three days. The study was conducted on 6-8 April 2018. The data of herpetofauna community were analyzed with Shannon-Wiener diversity index, Margalef richness index, and Pielou Evenness Index. The data of herpetofauna distribution were mapped and analyzed with Avenza and ArcGis. Based on the research conducted, we found 11 species of herpetofauna which consisted of five species from Ordo Anura, four species from Subordo Lacertilia, and two species from Subordo Serpentes. Herpetofauna in Watu Joglo was widely distributed around the river. According to diversity analysis, Watu Joglo has moderate diversity index, 1.667. Besides, Watu Joglo has high evenness index which is 0.85 but low richness index which is 2.83 .
\end{abstract}

\section{Introduction}

Herpetofauna plays important parts in the food web, energy flow, ecosystem balance, and sustainability. Most of them act as both predators and preys, which helps to maintain ecosystem population and community dynamics in check [1]. According to Valencia-Aguilar et al. [2], herpetofauna also serves various ecological services, such as provisioning, regulating, cultural, and supporting services. However, today the herpetofauna population tends to decline. The decline of herpetofauna population is caused by various factors, such as climate change, exploitation, disease outbreaks, species introduction, environmental pollution, to habitat destruction [3-4].

Various efforts can be made to conserve herpetofauna. One of the herpetofauna conservation efforts that can be done is to make an inventory of the herpetofauna community (such as diversity, richness, and evenness) and distribution of herpetofauna. Data on herpetofauna and the distribution of herpetofauna can be used as a baseline to determine the status of herpetofauna populations and as a reference for sustainable environmental management. Data on herpetofauna diversity and distribution will also provide a better understanding on herpetofauna community's microhabitat use and ecology, which can be used as a reference in herpetofauna community conservation.

Surveys on herpetofauna community have been carried out for various locations in the area of our current study, including Kembang Soka Waterfall Tourism Park area, Kedung Pedut Waterfall, Mudal River, Gumuk Pasir Parangkusuma, Goa Kiskendo Ecotourism, Girimulyo District, Sermo Wildlife Reserve, the southern and the western slope of Mount Merapi, Plawangan Hill, Opak River area, Gajah Wong river area, and Code River [5-12]. Based on the exploration of herpetofauna community, especially diversity that has been done, the diversity of reptiles in the Special Region of Yogyakarta reaches 47 species, and amphibians diversity reaches 23 species. However, there are still many locations that have not yet explored, one of which is Goa Watu Joglo. Thus, this study aimed to study and map the diversity, richness, evenness and distribution of herpetofauna in Watu Joglo cave area.

Watu Joglo is one of the caves located in the Sewu Mountain. Sewu Mountains are karst mountains that stretch from Gunung Kidul, Wonogiri to Pacitan. The area of Watu Joglo cave is estimated to be a good habitat

\footnotetext{
* Corresponding author: khadija.lung.ayu@mail.ugm.ac.id
} 

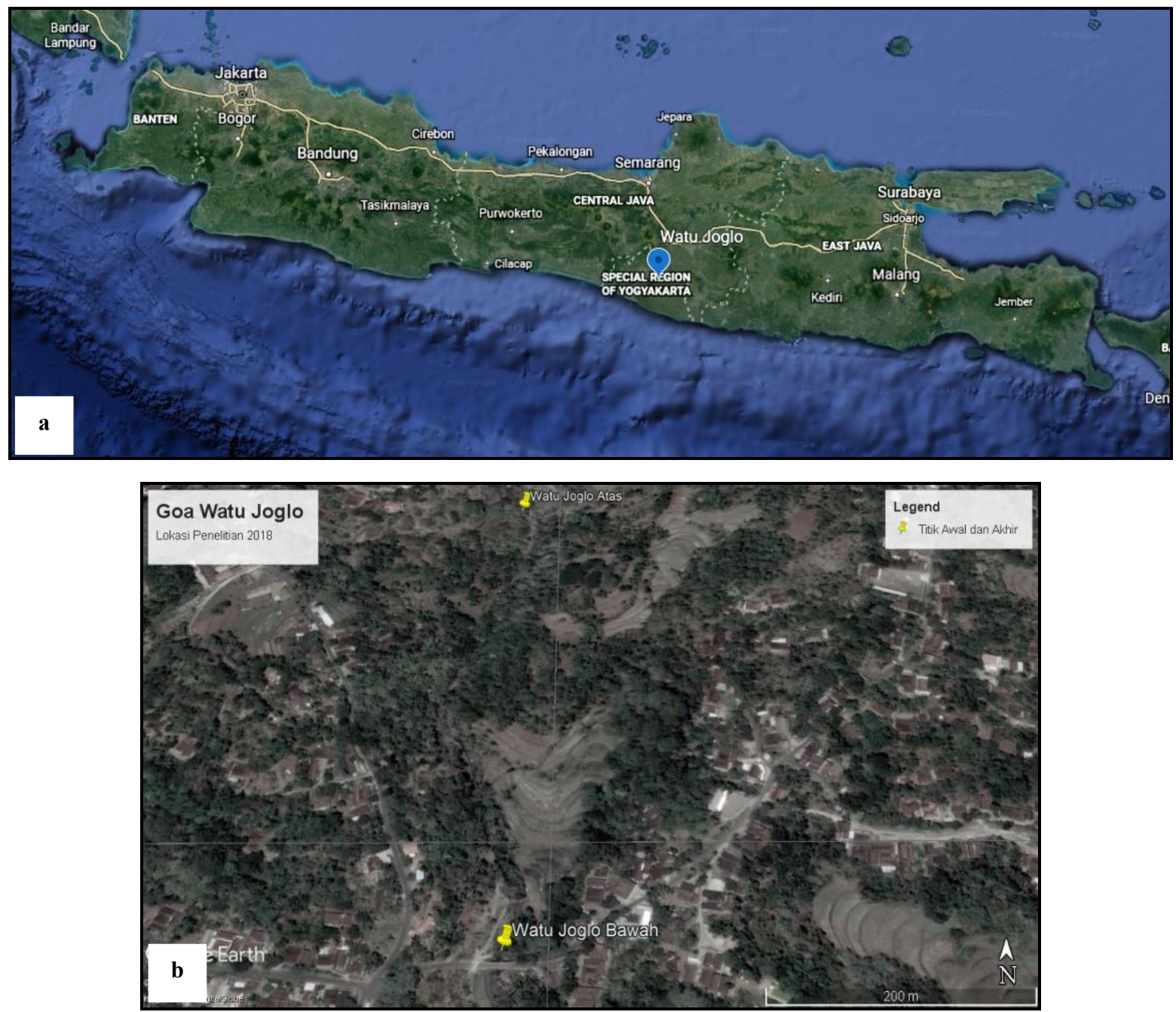

Fig. 1. Image of a) Java map and its relative position to research area and b) Watu Joglo cave location from Google Maps Satellite. (Google Earth, accessed on Tuesday, May 14, 2019, 3:04 p.m.)

for herpetofauna since the area bears various microhabitats. Microhabitat variations found in the area include caves, rivers, bushes, and trees. Since the survey area bears various microhabitats, it is estimated that we might found various herpetofauna; such as herpetofauna of which live in a wide range of microhabitats, or herpetofauna which lives in restricted microhabitats, such as a cave, river, tiny puddles, muds, or in a tree hole.

\section{Materials and methods}

\subsection{Research area}

This research was conducted in a river in Watu Joglo cave (Fig. 1), Kepil Hamlet, Putat Village, Pathuk District, Gunung Kidul Regency, Special Region of Yogyakarta. Sampling herpetofauna was conducted in three days from 6-8 April 2018. In general, the research location is in a rocky area surrounded by trees. There are rivers along with the location. The river length is $500 \mathrm{~m}$ characterized by large rocks, gravel with steep banks. The headwaters of the river are inside the cave. In the rainy season from the cave flowing water from the river above it. Water discharge is quite abundant in the rainy season and waterfalls emerge from the cave. Downstream is a dam for the local community's water needs. This river has average temperature of water and air $23-25^{\circ} \mathrm{C}$. Watu Joglo cave was opened to the public as an ecotourism area since 2014. But when the research was conducted, it was quiet and was never visited by visitors.

\subsection{Method}

The method used VES (Visual Encounter Survey) which combined Transect Method [13] along 500 meters and 50 sampling points. The sampling was carried out for three days two nights with three repetitions each for diurnal sampling and two repetitions for nocturnal sampling. The tools used in the study include a flashlight, 2-kilograms transparent plastic, permanent markers, scissors, callipers, metline, spring balance, syringe, cotton, bottle jam, and beaker glass. Specimens obtained directly identified using Kusrini et al. [14] and Das [15]. As for specimens that have not been identified directly in the field, preservation was carried out using $70 \%$ alcohol.

\footnotetext{
*Corresponding author: khadija.lung.ayu@mail.ugm.ac.id
} 


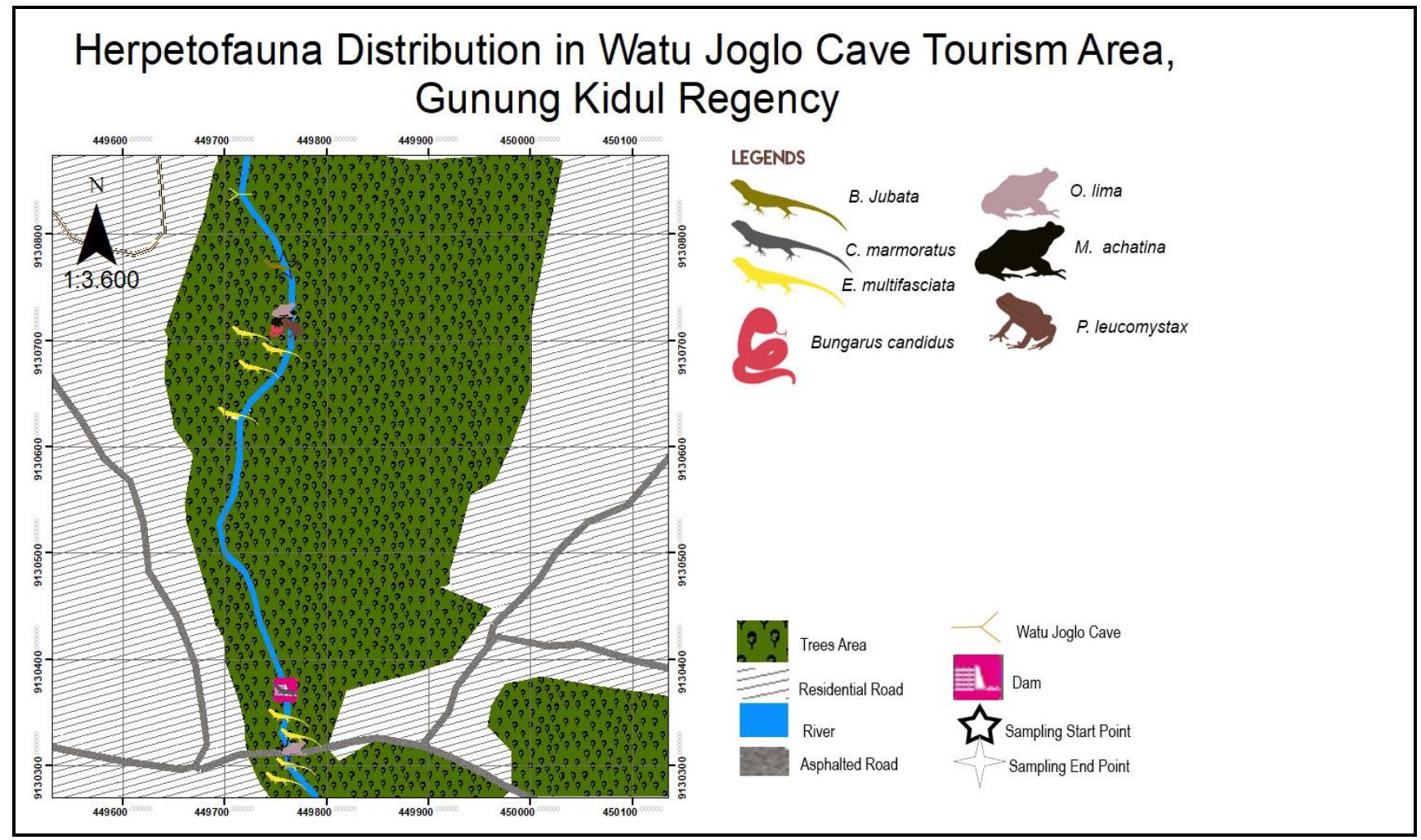

Fig. 2. Distribution of herpetofauna in Watu Joglo

\subsection{Data analysis}

We calculated herpetofauna diversity, evenness, dominance, and the level of similarity (similarity index) using the Shannon-Wiener Diversity Index [16].

$$
H^{\prime}=-\Sigma(p i \ln p i)
$$

Information:

$$
\begin{array}{ll}
\mathrm{H}^{\prime} & : \text { Shannon-Wiener index value } \\
\mathrm{Pi} & : \text { the value of the dominance of } \\
& \text { individuals in one community } \\
\mathrm{H}^{\prime}<1 & : \text { diversity is very low } \\
1.5<\mathrm{H}^{\prime}<2.0 & : \text { moderate diversity } \\
\mathrm{H}^{\prime}>2 & : \text { high diversity }
\end{array}
$$

As for the species abundance/ wealth index the Margalef Index is used [17].

$$
R=S-1 / \ln (N)
$$

Information:

$\mathrm{R}=$ Margalef Index

$\mathrm{S}=$ total species

$\mathrm{N}=$ total of individuals

To determine the homogeneity and distribution patterns of herpetofauna in the community, the Pielou Evenness Index [18] was used:

$$
E=H^{\prime} / \ln S
$$

Information:

$\mathrm{E}=$ Evenness index

$\mathrm{H}^{\prime}=$ Shannon -Wiener diversity index

$\mathrm{S}=$ Total of species

\section{Result and discussion}

We surveyed along the river emerging from the mouth of Watu Joglo cave and in the tree area by the riverside. The cave is a barrier of the study area to other river/ waterfalls. The study area (Fig. 2) was $500 \mathrm{~m}$ in length, with the mouth of the cave as the starting point. In general, the study area was a rocky river with an array of forest consisted of teak, banana, coconut trees, sapling of Ficus septica and Gliricida sepium, as well as ferns and grass by the riverside (Fig. 3). At a distance of $460 \mathrm{~m}$ from the starting point, there was a dam. Herpetofauna was commonly found in tree areas on either side of the river and around the dam area (Fig. 4). In the Watu Joglo cave area, 11 species were found with a total of 17 individuals found (Table 1).

Reptiles (classis: Reptilia) which were commonly found were Eutropis multifasciata with six individuals found, while Amphibian (classis: Amphibia) which were commonly found were Occidozyga lima with four individuals found. Aside from those species, there were some observed species but not caught and were identified to the level of genus, such as Occidozyga sp., Fejervarya sp., Draco sp., and Dendrelaphis sp.

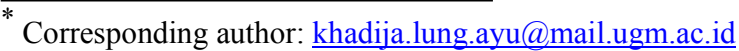




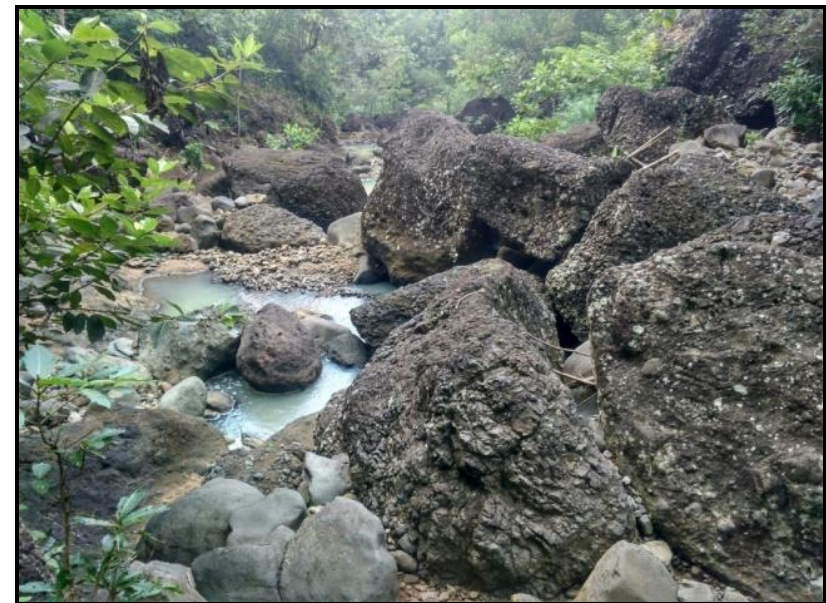

Fig. 3. The study area was a river with medium to large-sized rocks, with various plants around the river.

Occidozyga lima has a small and plump body with pearly spot spread all over the body. The frog has dorsal protruded eyes. $O$. lima was found during both night and day survey. According to Kurniati [19], O. lima is an aquatic frog which commonly found on the banks to the middle of a lake that is still shallow, where aquatic plants present.

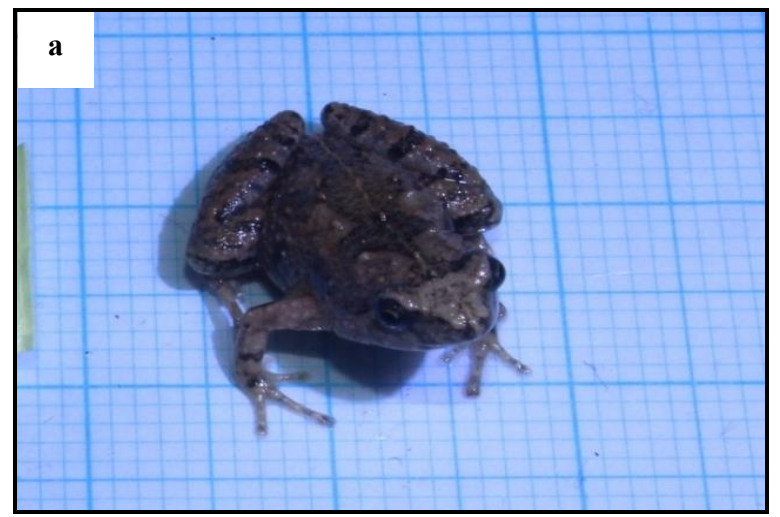

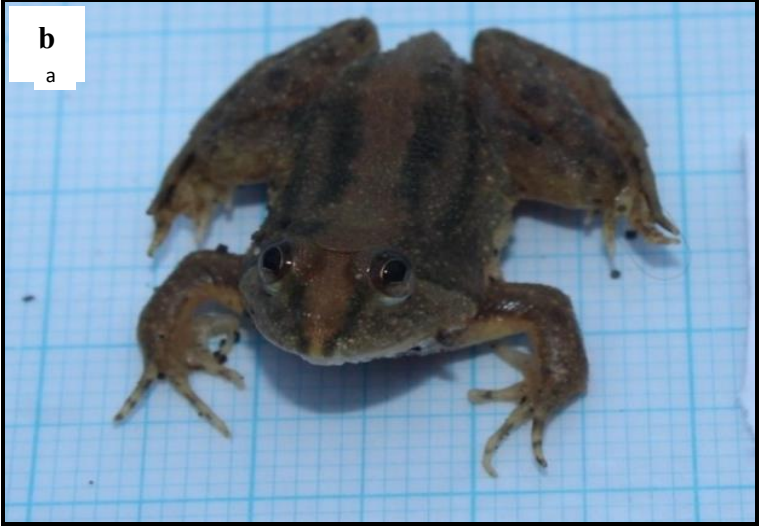
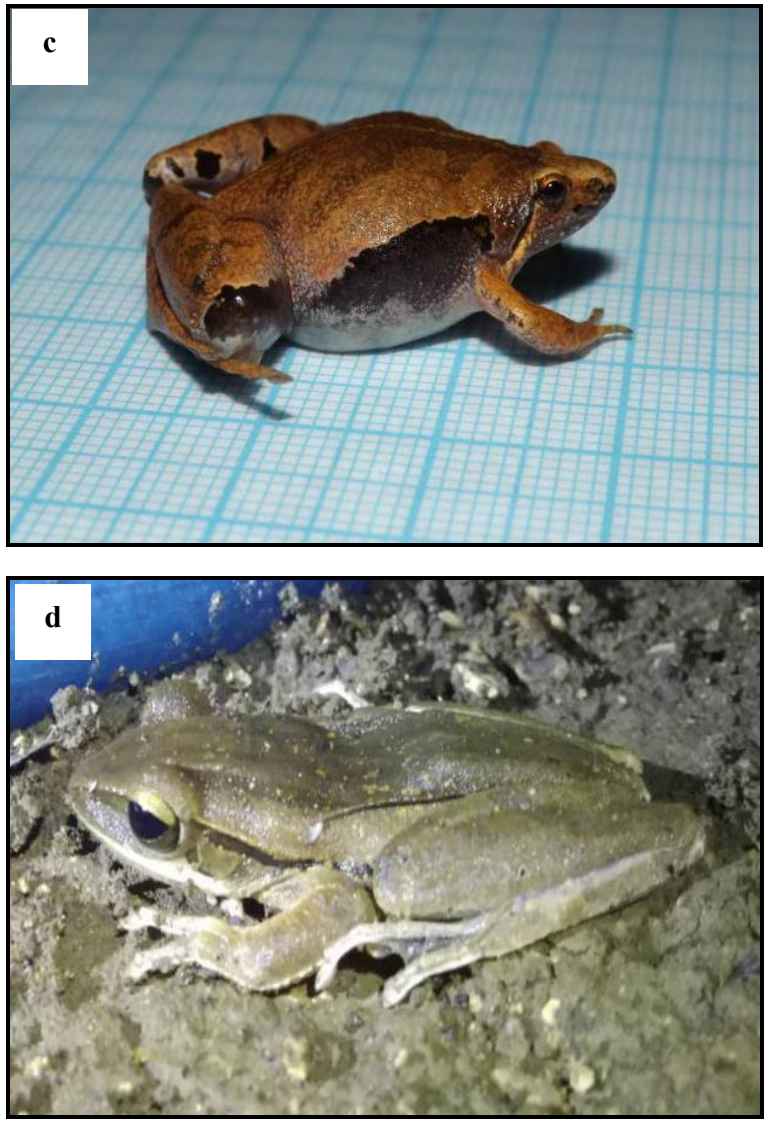

Fig. 4. a) Fejervarya sp., b) Occidozyga lima, c) Microhyla achatina, d) Polypedates leucomystax

Table 1. Species of herpetofauna found in the Watu Joglo

\begin{tabular}{|c|c|c|c|c|}
\hline Classis & $\begin{array}{l}\text { Ordo/ } \\
\text { Subordo }\end{array}$ & Familia & Spesies & Sindividu found \\
\hline \multirow[t]{5}{*}{ Amphibia } & Ordo Anura & Microhylidae & Microhyla achatina & 1 \\
\hline & & Dicroglossidae & Occidozyga lima & 4 \\
\hline & & & Occidozyga sp. & \\
\hline & & & Fejervarya sp. & \\
\hline & & Rhacophoridae & Polypedates leucomystax & 1 \\
\hline \multirow[t]{6}{*}{ Reptilia } & Subordo & Agamidae & Bronchocela jubata & 1 \\
\hline & Lacertilia & & Draco sp. & \\
\hline & & Gekkonidae & Cyrtodactylus marmoratus & 1 \\
\hline & & Scincidae & Eutropis multifasciata & 6 \\
\hline & Subordo & Elapidae & Bungarus candidus & 2 \\
\hline & Serpentes & Colubridae & Dendrelaphis sp. & 1 \\
\hline
\end{tabular}

\footnotetext{
$\overline{\text { * Corresponding author: khadija.lung.ayu } @ \text { mail.ugm.ac.id }}$
} 
According to Kusrini et al. [14], O. lima are commonly found swimming in rice fields. In this study O. lima was found in groups $40 \mathrm{~m}$ and $70 \mathrm{~m}$ away from the starting point. This specific position shows that the environment along the river is not identical and it means each sampling point perhaps be inhabited by different species depends on their microhabitat. This happens in $O$. lima at the site, they were found in the river and small ponds by the riverside which suitable for them to live. However, O. lima was also found in the dam area, $420 \mathrm{~m}$ away from starting point. At the site, O. lima was found on top of concrete in the form of a garden covered with wet litter (Fig. 5). The discovery of $O$. lima at this site does not correspond to its full aquatic habitat, but it is possible that at the time of discovery of $O$. lima was hunting or moving to another pond.

Microhyla achatina is a small frog in size of 20 to 25 $\mathrm{mm}$. The frog was found in night survey. According to Kusrini et al. [14], M. achatina is commonly found in grassy and moist banks of rivers or lakes. In the study, $M$. achatina was found among rocks and wet litters and muddy soil. During the study, $M$. achatina was found as many as one individual. This discovery is probably due to the fact that this species is more in open habitats such as rice fields and plantations and not frogs that are usually live in the forest [20].

Polypedates leucomystax is a tree frog that is commonly found in secondary forests, agricultural areas, as well as around human settlements [14, 21]. During the study, specimens were found at night surveys. Specimens were seen perched on tall grass and sapling. Sapling found in the study area was Gliricida sepium and Ficus septica.

Reptile that found in research area were Eutropis multifasciata, Bronchocela jubata, and Cyrtodactylus marmoratus (Fig. 6) as member of subordo Lacertilia, and Bungarus candidus as member of subordo Serpentes. Eutropis multifasciata was commonly found in this research. It is because E. multifasciata inhabits a variety of habitats. This species inhabit primary and secondary forest and even human settlement areas. This species is commonly found in rock and floor vegetation because E. multifasciata is terrestrial [15]. Based on the distribution map (Fig. 2), it is estimated that the distribution of this species is spread in the leaf litter along streams and rocks. E. multifasciata was found in rocks during the day and suspected to be basking.

Bronchocela jubata or Maned Forest Lizard is a member of the family Agamidae. In the site, Bronchocela jubata was found in trees around the river. This is in accordance with the habitat of Bronchocela jubata, which are green trees and saplings [22]. While tree species found around the river are Gliricidia sepium, Ficus septica, and Tectona spp. which has green leaves and is tall enough so that it can be used for protection and camouflage.

Cyrtodactylus marmoratus or Marbled Bow-fingered Gecko is a member of the Gekkonidae family. In the site, C. marmoratus was found in leaf litter near the dam. This is incompatible with the native habitat of $C$. mormoratus which is arboreal. However, this is possible because $C$. marmoratus can be found in degraded habitats [23]. It can be presumed that the individu found was looking for prey.

Bungarus candidus was the only snake caught in this survey. This species inhabits forests on low land, around settlements and agricultural areas. Bungarus candidus was found in a small pond on the river bank. This is incompatible with the behaviour of B. candidus which is terrestrial. It is suspected that individuals found are looking for anurans as prey.

Herpetofauna community structure can be demonstrated through various indicators, such as indicators of diversity, evenness, and species richness. In this research, community diversity is indicated by the Shannon-Wienner index, species richness is indicated by the Margalef index value, and evenness is indicated by the Pielou index value. The Shannon-Wienner index produce 1.667 where according to Brower \& Zarr [16], a diversity index value 1.5-2 indicates moderate diversity. Alikodra [24] states factors that influence the value of species diversity ( $\left.\mathrm{H}^{\prime}\right)$ are environmental conditions, the number of species and individuals distributions in each species.

According to Magurran [26] the differences in sample size can also affect the Shannon diversity index. Increase of sample size and number of individuals would increase the index value. In this research, the cause of moderate diversity is small number of
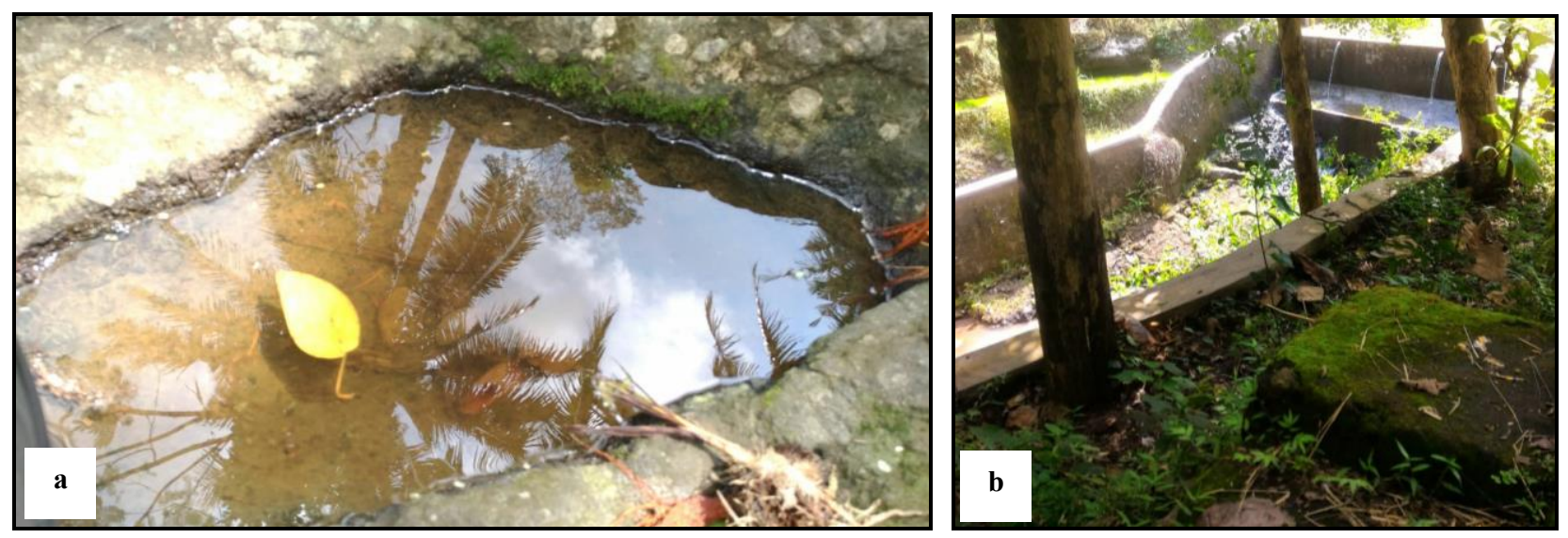

Fig. 5. Sampling site where $O$. lima found at a) river pond and b) dam area.

\footnotetext{
* Corresponding author: khadija.lung.ayu@mail.ugm.ac.id
} 
individuals per species. In addition, it can be caused by a less heterogeneous environmental condition so that the species found are limited to species that are able to live in an environment that is close to human activity.

The Pielou Index shows a value of 0.85 where according to Heip et al. [25] that the evenness index value ranges from 0 to 1 . The closer it is to 1 , the evenness of species in a community is higher. This shows the evenness of species in the herpetofauna community in Watu Joglo is high. This high evenness is due to the number of individuals of each species found generally the same which is one individu. The dominant species, Eutropis multifasciata, has six individuals that evenly distributed.

The Margalef Index shows a value of 2.83 where according to Magurran [26] that this value is mid-level richness. Species richness, defined as the number of species per unit area. The factors related to these species richness include (1) geographic factors such as scale of observation, available species pool and dispersal patterns; (2) biotic factors such as competition, predation and facilitation; and (3) abiotic environmental factors such as site resource availability, environmental heterogeneity, disturbance frequency and intensity, and physical conditions [27]. In this research, low value of species richness is suspected to be caused by a less heterogeneous environment, close to human settlements and is a tourist spot so that disturbance frequency and intensity are high.
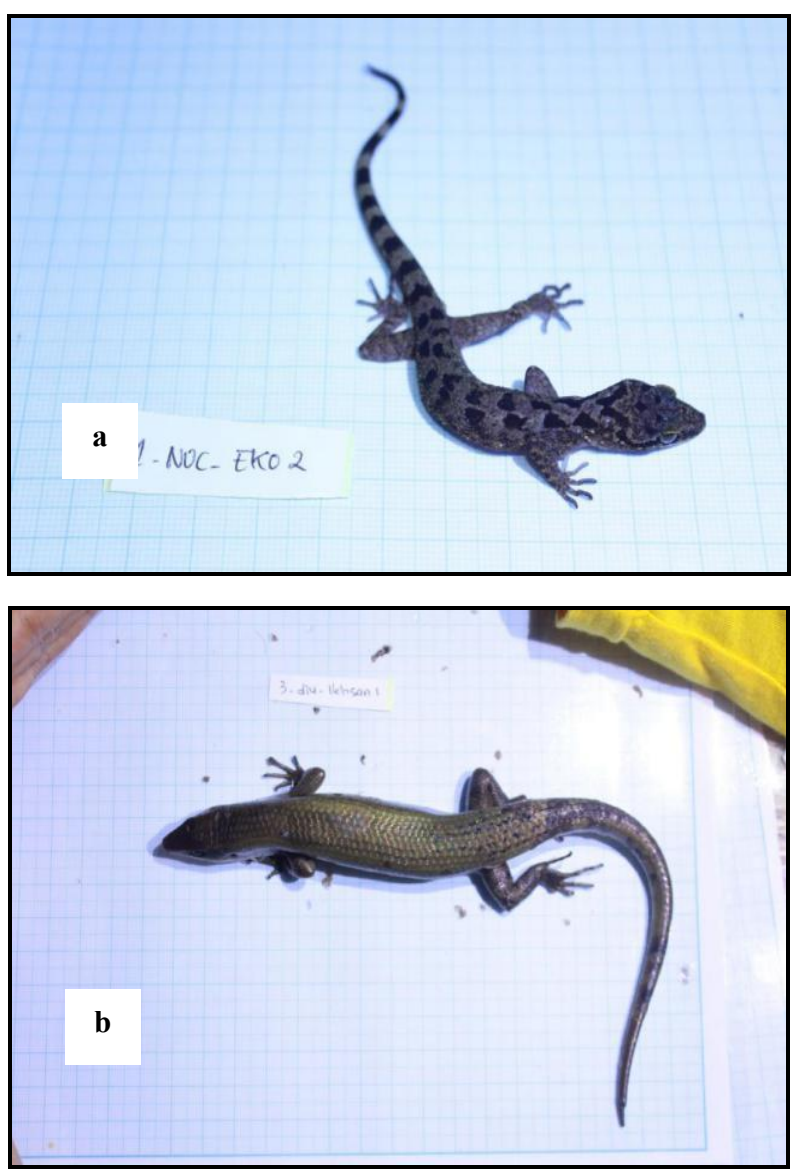

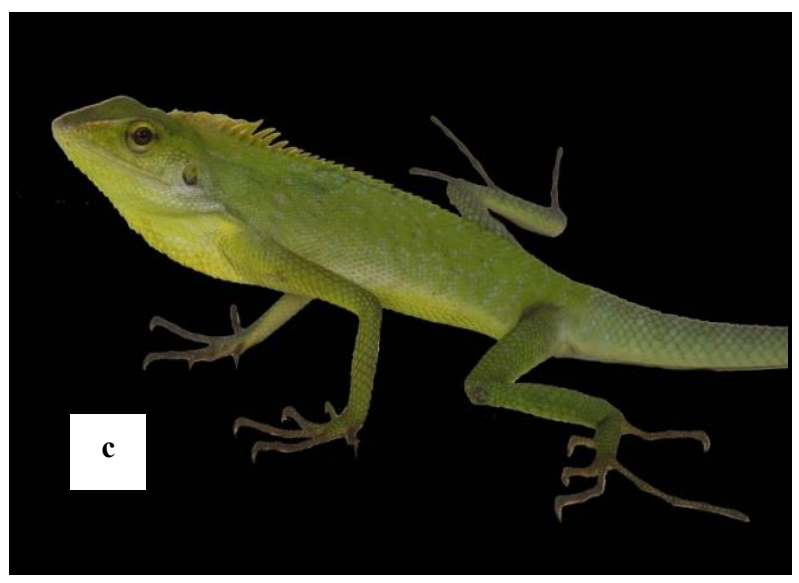

Fig. 6. a) Cyrtodactylus marmoratus, b) Eutropis multifasciata, c) Bronchocela jubata

\section{Conclusion}

In a study conducted in Watu Joglo Cave in 2018, 11 species were found, consisting of five species of ordo Anura, four species of subordo Lacertilia, and two species members of subordo Serpentes. The ShannonWienner Index shows a value of 1, 667 or moderate level of diversity. The Pielou index shows a value of 0.85 which is a high level of evenness, but the Margalef index shows a value of 2.83 or a low level of wealth. Herpetofauna in Watu Joglo is commonly found around rivers.

The author would like to thank all those who have assisted in the completion of this study, including the participants and the committee of the Herpetofauna Expedition Volume III: Gunung Kidul. We also thank Mr. Donan Satria Yudha as the supervisor of the Herpetology Study Group and as a guide in writing this paper for all input for the good of the author.

\section{References}

1. J. MacNeil, B. MacGowan, A. Currylow, R. Williams, Forest Management for Reptiles and Amphibians: A technical Guide for the Midwest (Purdue Extension, 2013) 10.13140/2.1.1977.9842

2. A. Valencia-Aguilar, A. Cortés-Gómez, C. RuizAgudelo, Int. j. biodivers. sci. ecosyst. serv. manag. 9, 3 (2013) 10.1080/21513732.2013.821168

3. A. Blaustein, D. Wake, W. Sousa, Conserv Biol, 8 (1994) DOI: $10.1046 /$ j.1523-1739.1994.08010060.x

4. B. Todd, J. Willson, J. Gibbons, The Global Status of Reptiles and Causes of their Declines. In: Ecotoxicology of Amphibians and Reptiles 2nd edition (CRC Press, Pensacola, 2010) DOI: 10.1201/EBK1420064162-c3

5. A. Fattah, I.M. Ummah, A. Parazulfa, N.L. Maireda, D. Fadhilah, E.P.S. Rizky, R. Eprilurrahman, Prosiding Semnas Biodiversitas 6, 3 (2017)

6. F. Kuswantoro, M.B. Atmaja, R.W. Permana, Trijoko, ICBS BIO-UGM (2011) 
7. A. Prasintaningrum, L. Faliha, D.S. Yudha, Prosiding Semnas Biodiversitas 6, 3 (2017)

8. T.F. Qurniawan, R. Eprilurahman. Zoo Indonesia 22, 2 (2013)

9. D.S. Yudha, R. Eprilurahman, K. Andryani, Trijoko, Berkala Ilmiah Biologi 12, 1 (2013)

10. D.S. Yudha, R. Eprilurahman, Trijoko, M.F. Alawi, A. Tarekat, Jurnal Biologi 18, 2 (2014)

11. D.S. Yudha, R. Eprilurahman, R. Pratiwi, I.A. Muhtianda, A. Arimbi, H.A. Asti. AIP Conf. Proc. 1744, 020013 (2016) doi: 10.1063/1.4953487

12. D.S. Yudha, R. Eprilurahman, A.M. Sukma, S.A. Setyaningrum. Biota 2, 2 (2017) https://doi.org/10.24002/biota.v2i2.1657

13. O. Springate-Baginski, D. Allen, W.R.T. Darwall, (eds.) An Integrated Wetland Assessment Toolkit: A guide to good practice (Gland, Switzerland: IUCN and Cambridge, UK: IUCN Species Programme, 2009)

14. M.D. Kusrini, W. Endarwin, M. Yazid, L.N. Rachman, A. Tajalli, Panduan Bergambar Identifikasi Amfibi Jawa Barat (Fakultas Kehutanan IPB dan Direktorat Koservasi Keanekaragaman Hayati, 2013)

15. I. Das, A Field Guide to the Reptiles of South-East Asia (New Holland Publishers (UK) Ltd., London, 2010).

16. J.E. Brower, J.H. Zarr, Field and Laboratory for General Ecology, (W.M.C Brown Company Publishing, Portugue, IOWA, 1997). In Qurniawan, T.F., Trijoko, T., Jurnal Tekno Sains 2, 1 (2012)

17. J.A. Ludwig, J.F. Reynolds, Statistical ecology: $a$ primer on methods and computing (John Willey and Sons, New York, 1988)

18. T.R.E. Southwood, Ecological methods (Chapman and Hall, London, 1971)

19. H. Kurniati, Berita Biologi 10, 3 (2010)

20. H. Kurniati, A. Sumadijaya, Jurnal Biologi Indonesia 8, 2 (2012)

21. J.L. McKay, A Field Guide to the Amphibians and Reptiles of Bali (Krieger Publishing Company, Malabar Florida, 2006)

22. I. Ineich, J. Hallermann, Bronchocela jubata. The IUCN Red List of Threatened Species 2010: e.T170378A6772283. https://dx.doi.org/10.2305/IU CN.UK.2010-4.RLTS.T170378A6772283.en

23. N. de Rooij, The reptiles of the Indo-Australian Archipelago. I Lacertilia, Chelonia, Emydosauria (E. J. Brill, Leiden, 1915)

24. H.S. Alikodra, Pengelolaan Satwa Liar, Jilid 1 (Fakultas Kehutanan, Institut Pertanian Bogor, Bogor, 2002)

25. C.H.R. Heip, P.M.J. Herman, K. Soetart, Oceanis 24, 4 (1998)

26. A.E. Magurran, Measuring Biological Diversity (Blackwell Publishing, Oxford, 2004) DOI: $10.2307 / 4126959$
27. R.L. Brown, L.A.J. Reilly, R.K. Peet, Species Richness: Small Scale. In: eLS. (John Wiley \& Sons, Ltd: Chichester, 2016) DOI: 10.1002/9780470015902.a0020488.pub2 